\title{
Problem Pengesahan Bendera Aceh dalam Negara Kesatuan Republik Indonesia (Pemetaan Permasalahan) ${ }^{1}$
}

\author{
Endra Wijaya,* Ricca Anggraeni, ${ }^{* *}$ Luh Rina Apriani***
}

\begin{abstract}
Abstrak
Bendera merupakan objek yang dapat dilekatkan beragam pesan dan makna terhadapnya. Keberadaan bendera bisa juga terkait dengan aspek simbol kedaulatan, sehingga wajar apabila kemudian sebagian pihak menganggap adanya bendera Aceh yang sama dengan bendera Gerakan Aceh Merdeka sebenarnya sudah membiarkan separatisme hidup di dalam Negara Kesatuan Republik Indonesia. Saat ini, di Aceh telah disahkan Qanun Aceh Nomor 3 Tahun 2013 tentang Bendera dan Lambang Aceh yang memberlakukan bendera berwarna merah dengan garis putih serta hitam dan gambar bulan sabit serta bintang sebagai bendera Aceh yang memiliki kesamaan dengan bendera GAM. Sejak masa konflik masih berlangsung hingga ke masa setelah ditandatanganinya Memorandum of Understanding antara Pemerintah Indonesia dan GAM, keberadaan bendera Aceh selalu menuai kontroversi dan menjadi isu hangat dalam praktik ketatanegaraan di NKRI. Keadaan ini mendorong pencarian penjelasan dan solusi khususnya dari sisi hukum.
\end{abstract}

Kata kunci: bendera, interpretasi, keadilan, Qanun Aceh, separatism.

\section{Aceh's Flag Problem in the Republic of Indonesia: Problem Mapping}

\begin{abstract}
Flag is an object in which many massages and meanings could be attached to. The existence of flag could also relate with sovereignty aspect and for that reason, some parties consider that the existence of Aceh's flag, which is same with Free Aceh Movement's (Gerakan Aceh Merdeka or GAM) flag, is conveying separatism in Republic of Indonesia. At present, in Nanggroë Aceh Darussalam, Aceh's Qanun Number 3 Year 2013 on Aceh's Flag and Symbol has been passed and its existence has always rises controversies and has become a problematic issue even after the signing of Memorandum of Understanding between the Government of Indonesia and GAM. It is thus an importance to discuss and try to find a solution for Aceh's flag problem especially from the law perspective.
\end{abstract}

Keywords: flag, interpretation, justice, Aceh's Qanun, separatism.

PADJADJARAN Jurnal IImu Hukum Volume 3 Nomor 1 Tahun 2016 [ISSN 2460-1543] [e-ISSN 2442-9325]

1 Merupakan ringkasan hasil laporan Penelitian Hibah Bersaing, Kementerian Pendidikan dan Kebudayaan Republik Indonesia, Direktorat Jenderal Pendidikan Tinggi, Direktorat Penelitian dan Pengabdian kepada Masyarakat, tahun 2013/2014.

* Dosen Fakultas Hukum Universitas Pancasila, Jl. Raya Lenteng Agung, Jakarta Selatan, endra.wijaya333@yahoo.co.id, S.H. (Universitas Pancasila), M.H. (Universitas Indonesia)

** Dosen Fakultas Hukum Universitas Pancasila, Jl. Raya Lenteng Agung, Jakarta Selatan, cha2 khan@yahoo.com, S.H., M.H. (Universitas Pancasila)

*** Dosen Fakultas Hukum Universitas Pancasila, Jl. Raya Lenteng Agung RT01/RW03, Jakarta Selatan, apriani.rina@yahoo.co.id, S.H., M.H. (Universitas Pancasila) 


\section{A. Pendahuluan}

Konflik yang pernah terjadi di Aceh antara Pemerintah Indonesia dengan Gerakan Aceh Merdeka (GAM) merupakan salah satu konflik yang masa berlangsungnya paling lama sejak Indonesia merdeka. Salah satu momen terpenting dalam upaya menyelesaikan konflik tersebut terjadi pada saat ditandatanganinya Memorandum of Understanding (MoU) antara Pemerintah Indonesia dan GAM di Helsinki, Finlandia, tanggal 15 Agustus 2005 (MoU Helsinki 2005). Pembentukan MoU Helsinki 2005 tersebut dilaksanakan melalui 5 (lima) babak pertemuan antara Pemerintah Indonesia dengan GAM yang diprakarsai oleh Ketua Crisis Management Initiative Finlandia, Martti Ahtisari, di Helsinki, Finlandia, sejak Januari 2005 sampai dengan tanggal 17 Juli 2005.

Setelah kesepahaman untuk berdamai antara antara Pemerintah Indonesia dengan GAM ditandatangani, banyak dinamika menarik yang terjadi di Aceh, terutama apabila dilihat dari perspektif hukum tata negara dan politik. Dinamika yang telah banyak menarik perhatian publik tersebut antara lain adalah mengenai keberadaan partai politik lokal di Aceh, eksistensi qanun, wali nanggroe, dan bendera Aceh.

Mengenai partisipasi politik di dalam MoU antara Pemerintah Indonesia dan GAM dijelaskan bahwa:

"Sesegera mungkin, tetapi tidak lebih dari satu tahun sejak penandatanganan Nota Kesepahaman ini, Pemerintah RI menyepakati dan akan memfasilitasi pembentukan partai-partai politik yang berbasis di Aceh yang memenuhi persyaratan nasional. Memahami aspirasi rakyat Aceh untuk partai-partai politik lokal, Pemerintah RI, dalam tempo satu tahun, atau paling lambat 18 bulan sejak penandatanganan Nota Kesepahaman ini, akan menciptakan kondisi politik dan hukum untuk pendirian partai politik lokal di Aceh dengan berkonsultasi dengan Dewan Perwakilan Rakyat."

Isi MoU yang memuat materi partisipasi politik tersebut pada intinya merupakan peluang yang diberikan kepada rakyat Aceh untuk terlibat atau berpartisipasi dalam perpolitikan di Aceh. Peluang yang tentu saja dampaknya bisa meluas ke bidang kehidupan yang lain, seperti bidang hukum dan ekonomi.

Ketentuan MoU tersebut juga menjadi landasan awal warga Aceh diperbolehkan untuk membentuk partai politik lokal sebagai kendaraan mereka dalam berpartisipasi secara politik di Aceh. Sebagai tindak lanjut dari MoU antara Pemerintah Indonesia dan GAM, Undang-Undang Nomor 11 Tahun 2006 tentang Pemerintahan Aceh (UU Pemerintahan Aceh 2006) dibentuk dan diundangkan, serta kemudian diikuti dengan dikeluarkannya Peraturan Pemerintah Nomor 20 Tahun 2007 tentang Partai Politik Lokal di Aceh (PP Parpol Lokal Aceh 2007).

Sejak gagasan pembentukan partai politik lokal di Aceh ini diajukan, pendapat 
yang mendukung ataupun yang menolaknya segera bermunculan. Namun demikian, terlepas dari adanya perbedaan pendapat tersebut, kini partai politik lokal di Aceh sudah menjadi fakta ketatanegaraan yang harus pula diakui pencapaiannya. Semenjak pemilihan Gubernur Aceh yang pertama setelah ditandatanganinya MoU antara Pemerintah Indonesia dan GAM, seluruh pejabat Gubernur Aceh yang terpilih ialah mereka yang berasal dari atau diusung oleh partai politik lokal di Aceh. Termasuk sisi komposisi keanggotaan dalam Dewan Perwakilan Rakyat Aceh (DPRA), baik untuk periode tahun 2009-2014 maupun periode tahun 2014-2019. Keanggotaan di DPRA mayoritas dikuasai oleh para wakil dari partai politik lokal di Aceh, khususnya Partai Aceh. ${ }^{2}$

Pencapaian dari unsur-unsur penggerak infrastruktur politik ${ }^{3}$ di Aceh terus berlanjut hingga kini. Kini unsur-unsur penggerak infrastruktur politik yang berhasil masuk ke dalam suprastruktur politik tersebut tidak hanya berhenti sampai menguasai jabatan kepala daerah di Aceh dan dominasi DPRA, namun telah berhasil pula mengesahkan keberadaan bendera Aceh melalui Qanun Aceh Nomor 3 Tahun 2013 tentang Bendera dan Lambang Aceh (Qanun Bendera dan Lambang Aceh 2013).

Tentunya perihal bendera Aceh ini segera menjadi isu hangat dalam praktik ketatanegaraan dan politik di Negara Kesatuan Republik Indonesia (NKRI) dengan alasan antara lain: pertama, gambar dan komposisi bentuk serta warna yang digunakan sebagai bendera Aceh faktanya sama dengan bendera GAM yang dianggap oleh Pemerintah Indonesia sebagai gerakan separatis. Bendera Aceh, begitu pun bendera GAM, terdiri dari unsur-unsur sebagai berikut: warna dasar merah, garis horizontal putih, garis horizontal hitam, bulan sabit, dan bintang.

Namun demikian, unsur-unsur tersebut tentu tidak hanya berhenti sebatas menyampaikan pesan visual dari gambar dan komposisi bentuk serta warna yang ada dalam bendera tadi. Lebih jauh daripada itu, unsur-unsur dalam bendera juga bisa membawa banyak pesan, termasuk pesan makna siapa kawan dan siapa lawan dalam suatu konteks hubungan tertentu. Hal seperti itulah yang disebut sebagai fungsi instrumental dari bendera sebagai pembawa pesan pembeda antara pihak yang satu dengan pihak yang lainnya. ${ }^{4}$

2 M. Rizwan Haji Ali dan Nezar Patria, “Dari Senjata ke Kotak Suara: Peralihan Gerakan Aceh Merdeka ke Politik Elektoral," Prisma 1, Vol. 28, Juni 2009: 99. Dapat dilihat juga Lintas Gayo, "Inilah 81 Calon Terpilih Anggota DPRA 2014-2019 dari 23 Kabupaten Kota," http://www.lintasgayo.com/48401/inilah-calon-terpilih-anggotadpra-2014-dari-23-kabupaten-dan-kota.html, diakses 19 Mei 2015.

3 Infrastruktur politik merupakan perwujudan kehidupan politik yang ada di masyarakat yang dapat memberikan pengaruh kepada tugas-tugas dari lembaga-lembaga negara dalam suasana pemerintahan. Unsur-unsur dari infrastruktur politik ini terdiri dari: partai politik, golongan kepentingan, golongan penekan, alat komunikasi politik, dan tokoh politik. Lihat Sri Soemantri, Tentang Lembaga-Lembaga Negara Menurut UUD 1945, Bandung: PT. Citra Aditya Bakti, 1993, hlm. 10.

4 Thomas Hylland Eriksen dan Richard Jenkins (eds.), Flag, Nation and Symbolism in Europe and America, London dan New York: Routledge, 2007, hlm. 3. 
Kedua, oleh sebagian pihak, penggunaan bendera yang sama dengan bendera GAM sebagai bendera Aceh ini dianggap sebagai tindakan yang bertentangan (melanggar) hukum, baik yang diatur dalam MoU maupun yang diatur dalam hukum positif seperti Peraturan Pemerintah Nomor 77 Tahun 2007 tentang Lambang Daerah (PP Lambang Daerah 2007). Pasal 6 ayat (4) PP Lambang Daerah 2007 itu secara eksplisit mengatur bahwa:

"Desain logo dan bendera daerah tidak boleh mempunyai persamaan pada pokoknya atau keseluruhannya dengan desain logo dan bendera organisasi terlarang atau organisasi/perkumpulan/lembaga/gerakan separatis dalam Negara Kesatuan Republik Indonesia."

Namun oleh sebagian pihak yang lain, bendera Aceh yang ternyata sama dengan bendera GAM tetap dianggap sebagai sesuatu yang wajar serta masih dapat diterima oleh sistem hukum yang berlaku di Indonesia.

Ketiga, mengenai bendera daerah, dalam hukum positif di Indonesia telah diatur di dalam beberapa peraturan perundang-undangan, yaitu: UU Pemerintahan Aceh 2006, PP Lambang Daerah 2007, dan Qanun Bendera dan Lambang Aceh 2013. Selain itu, MoU antara Pemerintah Indonesia dan GAM sebenarnya sudah pula menyinggung masalah keberadaan bendera ini, sebagaimana diatur dalam butir 1.1.5. yang berbunyi: "Aceh memiliki hak untuk menggunakan simbol-simbol wilayah termasuk bendera, lambang, dan himne."

Khusus terkait dengan bendera Aceh, maka sebenarnya keberadaan bendera tersebut telah memiliki landasan yuridis. Walaupun landasannya telah ada, tetapi bukan lantas keberadaan bendera Aceh ini tidak menjadi permasalahan (problem) ketatanegaraan. Keberadaan bendera bisa terkait dengan aspek simbol kedaulatan, ${ }^{5}$ sehingga wajar apabila kemudian sebagian pihak menganggap dengan adanya bendera Aceh yang sama dengan bendera GAM tersebut sebenarnya sudah membiarkan timbulnya 'negara di dalam negara', atau dengan kata lain telah membiarkan separatisme hidup di dalam NKRI.

Terlebih jika diperhatikan bahwa dari sisi sejarah, ternyata bendera juga merupakan simbol identitas sekaligus tujuan perjuangan yang diusung oleh gerakan politik ('kelompok pemberontak') tertentu. Kemudian pada saat mereka berhasil memenangkan pertarungan politik, maka bendera para pemberontak itulah yang kemudian menjadi bendera resmi negara. Pengalaman seperti itu dapat dilihat pada sejarah beberapa negara yang ada di benua Amerika. ${ }^{6}$

Keempat, bahkan pada level masyarakat Aceh sendiri, perdebatan mengenai bendera Aceh sudah muncul bahkan sebelum disahkannya Qanun Bendera dan Lambang Aceh 2013. Bendera dengan warna dasar merah, garis horizontal putih,

Christian Fogd Pedersen, The International Flag Book in Colour, London: Blandford Press, 1971, hlm. 6.

Ibid. 
garis horizontal hitam, bulan sabit dan bintang pernah menjadi 'rebutan' di antara para aktivis Partai GAM, sebelum berubah namanya menjadi Partai Aceh, dengan beberapa pihak di Aceh yang berargumen bahwa bendera tersebut seharusnya tidak menjadi monopoli partai politik tertentu karena bendera itu milik rakyat Aceh. ${ }^{7}$ Isu-isu mengenai keberadaan bendera Aceh sebagaimana telah dipaparkan tentunya menjadi 'sinyal' yang perlu segera ditanggapi. Hal tersebut bermakna bahwa masalah keberadaan bendera Aceh ini perlu dicarikan penjelasan dan solusinya, terutama dari sisi hukum.

\section{B. Permasalahan Ketidaksinkronan Pengaturan Peraturan Daerah}

Eksistensi peraturan daerah di Indonesia merupakan konsekuensi logis dari diterapkannya prinsip negara kesatuan bersifat desentralistis yang akan menghasilkan daerah otonom. Materi muatan peraturan daerah diatur dalam Pasal 14 Undang-Undang Nomor 12 Tahun 2011 tentang Pembentukan Peraturan Perundang-Undangan (UU P3 2011) yang menyatakan bahwa materi muatan peraturan daerah provinsi dan peraturan daerah kabupaten/kota berisi materi muatan dalam rangka penyelenggaraan otonomi daerah dan tugas pembantuan serta menampung kondisi khusus daerah dan/atau penjabaran lebih lanjut peraturan perundang-undangan yang lebih tinggi. Unsur menampung kondisi khusus dalam Pasal 14 tersebut terkait dengan kekhususan daerah yang dimaksud. Dalam khasanah peraturan perundang-undangan di tingkat daerah juga dikenal adanya peraturan daerah yang hanya dibentuk dan dikeluarkan di suatu daerah tertentu saja, yaitu: ${ }^{8}$

1. Peraturan Daerah Khusus (Perdasus);

2. Qanun; dan

3. Peraturan Daerah Istimewa (Perdais).

Qanun hanya ada di Provinsi Aceh. Menurut Pasal 1 butir 21 UU Pemerintahan Aceh 2006, Qanun Aceh adalah peraturan perundang-undangan sejenis peraturan daerah provinsi yang mengatur penyelenggaraan pemerintahan dan kehidupan masyarakat Aceh. Dengan demikian, qanun pada dasarnya sama dengan peraturan daerah. Persamaan qanun dengan peraturan daerah juga dapat dilihat dalam ketentuan Pasal 232 UU Pemerintahan Aceh 2006 yang menyatakan:

(1) Qanun Aceh disahkan oleh Gubenur setelah mendapat persetujuan bersama dengan Dewan Perwakilan Rakyat Aceh.

(2) Qanun Kabupaten/Kota disahkan oleh Bupati/Walikota setelah mendapat persetujuan bersama dengan Dewan Perwakilan Rakyat Kabupaten/Kota.

\footnotetext{
Taufik Al Mubarak, Aceh Pungo, Banda Aceh: Bandar Publishing, 2009, hlm. 266-267.

8 Hestu Cipta Handoyo, Prinsip-Prinsip Legal Drafting dan Desain Naskah Akademik, Yogyakarta: Cahaya Atma Pustaka, 2014, hlm. 136.
} 
Walaupun qanun sama dan setingkat dengan peraturan daerah, tetapi qanun memiliki materi muatan yang berbeda dengan materi muatan peraturan daerah pada umumnya. Namun demikian, perlu diketahui pula bahwa pembentukan peraturan perundang-undangan di tingkat daerah juga harus tunduk pada asas-asas pembentukan peraturan perundang-undangan yang baik sebagaimana diatur dalam UU P3 2011. Salah satu asas yang dimaksud adalah asas kenusantaraan, yakni bahwa setiap materi muatan peraturan perundang-undangan senantiasa harus memperhatikan kepentingan seluruh wilayah Indonesia dan materi muatan peraturan perundang-undangan yang dibuat di daerah merupakan bagian dari sistem hukum nasional yang berdasarkan Pancasila dan Undang-Undang Dasar Negara Republik Indonesia Tahun 1945 (UUD 1945). Oleh sebab itu, peraturan perundang-undangan di daerah tidak boleh bertentangan dengan peraturan perundang-undangan yang lebih tinggi (peraturan perundang-undangan di tingkat pusat).

Apabila Eksistensi Qanun Bendera dan Lambang Aceh 2013 yang 'menggunakan' bendera GAM sebagai bendera Aceh dilihat melalui pendekatan Stufentheorie dari Hans Kelsen, maka dapat dikatakan bahwa qanun tersebut bertentangan dengan Pasal 6 ayat (4) PP Lambang Daerah 2007. Pertentangan tersebut antara lain dapat dilihat pada bagian dasar pertimbangan Qanun Bendera Aceh 2013 yang menggunakan MoU Helsinki 2005 sebagai dasar hukum pembentukannya. Hal itu jelas tidak valid, karena seharusnya qanun dibentuk dengan didasarkan kepada peraturan perundang-undangan yang lebih tinggi kedudukannya.

Dalam mengatasi keadaan tersebut, maka pemerintah pusat harus melakukan penyelarasan, harmonisasi, dan sinkronisasi terhadap Qanun Bendera dan Lambang Aceh 2013 agar tidak bertentangan dengan peraturan perundangundangan di tingkat pusat. Apabila Qanun Bendera dan Lambang Aceh 2013 secara yuridis dan teoretis tidak memiliki validitas, maka implikasi hukum yang terjadi adalah qanun tersebut tidak memiliki kekuatan hukum mengikat dan dapat dibatalkan oleh pemerintah pusat.

Mengenai ketidaksinkronan pengaturan terkait bendera Aceh ini, pada bulan April 2013 pemerintah pusat telah melakukan klarifikasi resmi yang menyatakan bahwa Qanun Bendera dan Lambang Aceh 2013 bertentangan dengan peraturan perundang-undangan. Surat klarifikasi dikeluarkan oleh Menteri Dalam Negeri dan ditujukan kepada Pemerintah Aceh dengan harapan bahwa Pemerintah Aceh dapat segera merespons dan menindaklanjutinya. Namun hingga sekarang belum ada tindak lanjut yang dilakukan oleh Pemerintah Aceh terkait dengan klarifikasi tersebut. ${ }^{9}$

9 Wawancara tim peneliti dengan Pejabat Kepala Seksi Pemerintahan Aceh, Direktorat Jenderal Otonomi Daerah, Kementerian Dalam Negeri. Wawancara dilakukan di kantor Direktorat Jenderal Otonomi Daerah, 
Akibat tidak ditindaklanjuti surat klarifikasi yang ditujukan kepada Pemerintah Aceh, akhirnya Kementerian Dalam Negeri mengajukan Rancangan Peraturan Presiden tentang Pembatalan Qanun Aceh Nomor 3 Tahun 2013 (Rancangan PP Pembatalan Qanun Bendera dan Lambang Aceh 2013) melalui Sekretariat Negara, ${ }^{10}$ namun hal itu belum mendapat respons yang baik pula dari Sekretariat Negara. Kemudian muncul pertanyaan mengenai apa yang seharusnya dilakukan Pemerintah Pusat untuk menindak lanjuti Qanun Aceh Nomor 3 Tahun 2013 tersebut. Hal ini dikarenakan Pemerintah Pusat, melalui Kementerian Dalam Negeri, tentu saja dapat membatalkan qanun itu dengan dasar hukum Pasal 251 jo Pasal 250 ayat (1) dan ayat (2) Undang-Undang Nomor 23 Tahun 2014 tentang Pemerintahan Daerah (UU Pemda 2014).

\section{Sensitivitas Persoalan Bendera dalam Konteks Negara Berdaulat}

Bendera merupakan objek yang dapat menimbulkan kontroversi. Sama halnya terdapat beberapa bendera telah menjadi objek yang dilarang untuk dikibarkan di Indonesia dan apabila tetap dikibarkan, maka hal itu akan menjadi problem keamanan yang segera direspons oleh pihak yang berwenang. Sebagai contoh, bendera-bendera seperti bendera palu dan arit milik Partai Komunis Indonesia (PKI), bendera benang raja yang digunakan oleh gerakan Republik Maluku Selatan (RMS), dan bendera bintang kejora yang digunakan oleh Organisasi Papua Merdeka (OPM) merupakan objek yang dilarang untuk dikibarkan. Sensitivitas problem bendera juga melekat pada bendera bulan sabit dan bintang yang saat ini telah disahkan sebagai bendera Aceh melalui Qanun Bendera dan Lambang Aceh 2013. Penyebab dari problem bendera Aceh tersebut adalah karena bendera Aceh oleh sebagian pihak masih dianggap memiliki keterkaitan dengan GAM.

Keberadaan semua bendera yang disebutkan di atas menjadi sensitif terutama dikarenakan bendera-bendera tersebut berhubungan erat dengan aktivitas yang dianggap membahayakan negara. Dalam istilah PP Lambang Daerah 2007, benderabendera semacam itu disebut sebagai "bendera organisasi terlarang atau organisasi/perkumpulan/lembaga/gerakan separatis dalam Negara Kesatuan Republik Indonesia." Dengan demikian, dapat dipahami bahwa bendera ialah objek yang juga harus diperhitungkan saat membicarakan konsep kedaulatan suatu negara.

Menurut Mochtar Kusumaatmadja, kedaulatan dapat dipahami sebagai kekuasaan yang tertinggi, ${ }^{11}$ sehingga suatu negara berdaulat tidak mengakui adanya

Kementerian Dalam Negeri, Jakarta, pada tanggal 3 November 2014.

10 Sebelum berlakunya Undang-Undang Nomor 23 Tahun 2014 tentang Pemerintah Daerah (UU Pemda 2014), pihak kementerian tidak memilki wewenang untuk membatalkan peraturan daerah, wewenang itu berada pada tangan Presiden.

11 Mochtar Kusumaatmadja dan Etty R. Agoes, Pengantar Hukum Internasional, Bandung: Alumni, 2003, hlm. 17. Penjelasan mengenai konsep kedaulatan dalam pemikiran Mochtar Kusumaatmadja ini dimuat juga dalam 
kekuasaan yang lebih tinggi daripada kekuasaannya sendiri. ${ }^{12}$ Namun demikian, menurut Mochtar, kekuasaan tertinggi yang dimiliki oleh suatu negara mengandung 2 (dua) pembatasan penting dalam dirinya, yaitu: $:^{13}$ pertama, kekuasaan itu terbatas pada batas wilayah negara yang memiliki kekuasaan itu; dan kedua, kekuasaan itu berakhir di mana kekuasaan suatu negara mulai.

Sebagai akibat dari pemahaman kedaulatan yang terbatas tersebut, maka terdapat aspek-aspek lain yang melekat di antara negara-negara berdaulat, yakni kemerdekaan (independence) dan persamaan derajat (equality). Oleh karena itu, sebagaimana diungkapkan oleh Mochtar, 3 (tiga) konsep yaitu kedaulatan, kemerdekaan, dan persamaan derajat merupakan konsep yang saling terkait dan tidak bertentangan antara yang satu dengan yang lain. ${ }^{14}$

Selain kedua pembatasan itu, Mochtar juga menambahkan lagi pembatasan kedaulatan yang dilakukan oleh hukum internasional. ${ }^{15}$ Hukum internasional akan berfungsi sebagai pengatur kehidupan masyarakat antarnegara (masyarakat internasional). Sehingga dalam kata lain, masyarakat internasional yang teratur tidak mungkin akan dicapai tanpa adanya sikap menerima pembatasan yang dilakukan melalui instrumen hukum internasional terhadap kedaulatan yang dimiliki negara-negara yang menjadi anggota dari masyarakat internasional. ${ }^{16}$

Mochtar juga telah memberikan penjelasan mengenai hukum internasional dalam buku Pengantar Hukum Internasional, yakni sebagai berikut:

"Hukum internasional merupakan suatu tertib hukum koordinasi antara anggota-anggota masyarakat internasional yang sederajat. Anggota masyarakat internasional tunduk pada hukum internasional sebagai suatu tertib hukum yang mereka terima sebagai perangkat kaedah dan asas yang mengikat dalam hubungan antarmereka."17

Pemikiran lainnya dari Mochtar yang berkaitan erat dengan masalah kedaulatan, baik kedaulatan yang bersifat fisik (wilayah) maupun nonfisik (politik, ekonomi, kebudayaan, pertahanan dan keamanan), ialah pemikirannya tentang konsep wawasan nusantara. Menurut Mochtar, konsep wawasan nusantara merupakan "konsepsi kesatuan wilayah, bangsa dan negara yang memandang Indonesia sebagai suatu kesatuan yang meliputi tanah (darat) dan air (laut) secara tidak terpisahkan...". ${ }^{18}$ Lebih lanjut Mochtar menjelaskan bahwa wawasan

Deni Bram dan Endra Wijaya, "Pemaknaan Ulang Konsep Kedaulatan Mochtar Kusuma-Atmadja Dalam Ranah Hukum Lingkungan Internasional," dimuat dalam Shidarta (eds.), Mochtar Kusuma-Atmadja dan Teori Hukum Pembangunan: Eksistensi dan Implikasi, Jakarta: Epistema Institute dan HuMa, 2012.

12 Ibid.

13 Ibid., hlm. 18.

14 Ibid., hlm. 19.

15 Ibid.

16 Ibid.

17 Ibid., hlm. 9.

18 Mochtar Kusumaatmadja, Bunga Rampai Hukum Laut, Bandung: Bina Cipta, 1978, hlm. 41. 
nusantara, sebagai suatu wawasan kesatuan bangsa dan Negara Indonesia, meliputi bidang-bidang kehidupan yang terdiri dari: politik, ekonomi, kebudayaan, dan pertahanan serta keamanan. ${ }^{19}$

Sebelum konsep wawasan nusantara dilahirkan, telah ada konsep nusantara (archipelago concept). Menurut Mochtar, konsep nusantara merupakan konsepsi kewilayahan nasional. ${ }^{20}$ Konsep nusantara ini dirumuskan dengan mempertimbangkan aspek pertahanan serta keamanan dan upaya untuk menjamin integritas teritorial dari wilayah Indonesia sebagai satu-kesatuan yang bulat yang meliputi unsur tanah (darat) dan air (laut). ${ }^{21}$

Secara historis dengan memperhatikan hubungan di antara kedua konsep tersebut, dapat dipahami bahwa konsep wawasan nusantara itu merupakan 'kelanjutan' dari konsep nusantara yang telah dimulai sejak akhir tahun $1957 .^{22}$ Namun tidak hanya berhenti sampai di situ, secara implisit Mochtar juga telah menjelaskan bahwa ada 3 (tiga) tahapan yang sebenarnya merupakan rangkaian dari gerakan pembangunan nasional yang kokoh serta menghubungkan konsep nusantara dan wawasan nusantara. Ketiga tahap yang dimaksud adalah: ${ }^{23}$

1. Tahap mencetuskan, memperkenalkan, memperjuangkan, dan mempertahankan konsep nusantara dengan segala cara yang sah, di segala forum yang tersedia, baik di tingkat nasional maupun internasional. Dasar hukum dari konsep nusantara awalnya terdapat di dalam Deklarasi 13 Desember 1957 (Deklarasi Djuanda) dan kemudian ditetapkan sebagai Undang-Undang Nomor 4/Prp. Tahun 1960 tentang Perairan Indonesia (UU Perairan Indonesia 1960). ${ }^{24}$ Capaian dari tahap ini ialah lahirnya wilayah negara nusantara (negara kepulauan) dengan tanah dan airnya merupakan satu-kesatuan yang utuh dan tidak terpisahkan. ${ }^{25}$

2. Tahap perkembangan dari konsep nusantara ke arah konsep wawasan nusantara. Tahap ini ditandai dengan dikeluarkannya Ketetapan Majelis Permusyawaratan Rakyat Nomor IV/MPR/1973 tentang Wawasan Nusantara (Tap MPR tentang Wawasan Nusantara 1973). Dalam tahap ini, konsep nusantara (sebagai konsep kesatuan wilayah) dijadikan sebagai dasar konsep pembangunan nasional yang lebih luas dengan tidak hanya meliputi aspek kewilayahan semata-mata, tetapi juga meliputi bidang-bidang kehidupan lainnya.

\footnotetext{
Ibid., hlm. 42.

Ibid.

lbid., hlm. 27-28.

lbid., hlm. 45.

Mochtar Kusumaatmadja, Op.cit., hlm. 160.

Ibid., hlm. 31.

Ibid., hlm. 45.
} 
3. Tahap mewujudkan konsep wawasan nusantara ke dalam bidang-bidang kehidupan berbangsa dan bernegara yang disebutkan dalam Garis-Garis Besar Haluan Negara (GBHN), yaitu bidang politik, ekonomi, kebudayaan, serta pertahanan dan keamanan, sehingga konsep berkembang menjadi suatu doktrin nasional yang dapat dijadikan pedoman kebijakan (policy) nasional yang kuat.

Dari penjelasan tersebut, maka dapat dipahami pula terdapat perbedaan antara konsep nusantara dan konsep wawasan nusantara. Konsep nusantara hanya merupakan konsep kewilayahan nasional, sedangkan konsep wawasan nusantara merupakan konsep kesatuan politik dari bangsa dan negara yang didasarkan atas konsep kewilayahan nasional tersebut. Dengan kata lain, kesatuan tanah dan air (aspek teritorial) yang terkandung dalam konsep nusantara merupakan 'wadah fisik' bagi pengembangan wawasan nusantara. ${ }^{26}$

Dalam praktiknya, beberapa aspek yang terkandung di dalam konsep kedaulatan tersebut tentunya memerlukan simbol, yang dapat berupa bendera, untuk memudahkan warga negara yang berada dalam lingkup negara memahami secara simbolis bahwa mereka ialah bagian yang tidak terpisahkan dari kedaulatan negara mereka. Selain itu, warga negara yang anggotanya berjumlah banyak kemudian secara simbolis juga akan diikat atau dipersatukan melalui bendera, sehingga apabila ada gangguan dari pihak tertentu yang juga memiliki bendera sendiri terhadap satu-kesatuan ikatan politik, ekonomi, kebudayaan, dan pertahanan serta keamanan; lantas bendera dari pihak itu otomatis tentu akan dianggap pula sebagai objek yang mengganggu kedaulatan dan rasa persatuan warga negara tadi. Jika keadaan seperti itu terjadi, maka negara 'yang sah' akan menjadikan bendera dari pihak yang 'tidak sah' tersebut sebagai objek yang dilarang keberadaannya, apalagi untuk dikibarkan.

Secara yuridis, hal-hal yang baru saja dijelaskan di atas sebenarnya memiliki landasan hukum dalam UUD 1945 dan Undang-Undang Nomor 24 Tahun 2009 tentang Bendera, Bahasa, dan Lambang Negara, serta Lagu Kebangsaan (UU Kebangsaan 2009). Selain itu, pernah berlaku pula Peraturan Pemerintah Nomor 40 Tahun 1958 tentang Bendera Kebangsaan Republik Indonesia (PP Bendera Indonesia 1958).

Bagian Menimbang huruf a dan b dalam UU Kebangsaan 2009 menjelaskan bahwa:

"a. bahwa bendera, bahasa, dan lambang negara, serta lagu kebangsaan Indonesia merupakan sarana pemersatu, identitas, dan wujud eksistensi bangsa yang menjadi simbol kedaulatan dan kehormatan negara sebagaimana diamanatkan dalam Undang- 
Undang Dasar Negara Republik Indonesia Tahun 1945; b. bahwa bendera, bahasa, dan lambang negara, serta lagu kebangsaan Indonesia merupakan manifestasi kebudayaan yang berakar pada sejarah perjuangan bangsa, kesatuan dalam keragaman budaya, dan kesamaan dalam mewujudkan cita-cita bangsa dan Negara Kesatuan Republik Indonesia;..." (huruf miring oleh penulis)

Lebih lanjut, Penjelasan Umum UU Kebangsaan 2009 juga menjelaskan bahwa:

"Bendera Negara Sang Merah Putih, Bahasa Indonesia, Lambang Negara Garuda Pancasila, dan Lagu Kebangsaan Indonesia Raya merupakan jati diri bangsa dan identitas Negara Kesatuan Republik Indonesia. Keempat simbol tersebut menjadi cerminan kedaulatan negara di dalam tata pergaulan dengan negara-negara lain dan menjadi cerminan kemandirian dan eksistensi negara Indonesia yang merdeka, bersatu, berdaulat, adil dan makmur. Dengan demikian, bendera, bahasa, dan lambang negara, serta lagu kebangsaan Indonesia bukan hanya sekadar merupakan pengakuan atas Indonesia sebagai bangsa dan negara, melainkan menjadi simbol atau lambang negara yang dihormati dan dibanggakan warga negara Indonesia. Bendera, bahasa, dan lambang negara, serta lagu kebangsaan Indonesia menjadi kekuatan yang sanggup menghimpun serpihan sejarah Nusantara yang beragam sebagai bangsa besar dan Negara Kesatuan Republik Indonesia..." (huruf miring oleh penulis)

Kutipan-kutipan di atas memperlihatkan bahwa antara bendera, identitas, dan kedaulatan bangsa serta negara merupakan unsur-unsur yang saling berkaitan. Dan hal seperti itu tentu saja tidak hanya berlaku bagi Indonesia, tetapi juga bagi negaranegara lain.

Melekatnya ketiga unsur, yaitu bendera; identitas; dan kedaulatan bangsa serta negara dapat dijelaskan secara semiotik. Secara sederhana, dalam kajian semiotik dapat dijelaskan bahwa proses pemaknaan suatu objek tanda, seperti halnya bendera, paling sedikit melibatkan unsur penanda dan unsur petanda. Penanda merupakan citra yang terbentuk dalam kognisi pemakai tanda yang berupa bunyi, warna, bangun, atau hal lain yang ada dalam kehidupan. Sedangkan petanda merupakan makna atau isi yang dipahami manusia pemakai tanda. ${ }^{27}$

Tanda sebagai suatu proses adalah proses saling berkaitannya penanda dan petanda yang disebut sebagai proses pemaknaan. Alur pemikiran seperti itulah yang tampaknya digunakan juga oleh beberapa peraturan perundang-undangan yang mengatur mengenai bendera di Indonesia. Bendera sebagai penanda dapat dimaknai sebagai sesuatu yang positif maupun negatif. Bendera menjadi sesuatu

27 Benny H. Hoed, Semiotik dan Dinamika Sosial Budaya, Depok: Fakultas Ilmu Pengetahuan Budaya Universitas Indonesia, 2008, hIm. 1-2 dan 8. 
yang dimaknai positif ketika dia dimuati pesan "sarana pemersatu, identitas, dan wujud eksistensi bangsa yang menjadi simbol kedaulatan dan kehormatan negara" seperti yang dicantumkan antara lain dalam UU Kebangsaan 2009. Namun ketika bendera 'dicurigai' dimuati oleh ide 'separatis', maka lantas bendera diletakkan pada posisi makna yang negatif.

\section{Bendera Bulan Sabit dan Bintang}

\section{Kaitan Bendera Bulan Sabit dan Bintang dengan Persoalan Ketidakadilan}

Munculnya bendera bulan sabit dan bintang dalam konteks politik kekinian di Aceh sebenarnya sejalan dengan munculnya fenomena partai politik lokal di Aceh. Dan jika ditelusuri lebih jauh ke belakang, maka kedua fenomena tersebut berkaitan dengan munculnya gerakan perlawanan (separatisme) terhadap pemerintah pusat yang diperankan salah satunya oleh GAM.

Beberapa pendapat telah diungkapkan oleh para ahli mengenai faktor-faktor yang menyebabkan timbulnya separatisme, khususnya dalam wilayah NKRI. Menurut pendapat J. Kristiadi, separatisme akan timbul karena adanya ketidakadilan, kesewenang-wenangan, tersumbatnya aspirasi di suatu daerah, dan segala bentuk penyalahgunaan kekuasaan lainnya. ${ }^{28}$ Beberapa provinsi seperti Aceh dan Papua pernah menuntut kemerdekaan dan alasan utama dari tuntutan kemerdekaan itu adalah bahwa meski kedua wilayah itu sudah puluhan tahun menjadi bagian dari NKRI, mereka bukan saja merasa nasibnya terabaikan, tetapi juga mengalami penindasan oleh pemegang kekuasaan di pusat. ${ }^{29}$

Eko Prasojo menjelaskan hal yang sejalan dengan apa yang telah diungkapkan oleh Kristiadi, yakni sebagai berikut: ${ }^{30}$

"Politik sentralisme dan praktik ketidakadilan yang terjadi selama masa Soeharto telah menyebabkan gerakan separatisme di beberapa daerah. Ketidakseimbangan pembagian keuangan antara pusat dan daerah telah menyebabkan kecemburuan di beberapa daerah. Kekayaan alam di Aceh yang diekspor menghasilkan keuntungan US\$ 2 milyar pada tahun 1997 hanya memberikan manfaat kepada masyarakat Aceh sebesar 0,05\% melalui APBN... Sedangkan PT. Freeport yang mengeruk keuntungan tahun 1997 US\$1,1 milyar, tetapi masyarakat Papua tetap hidup seperti pada zaman batu."

Alasan tersebut juga telah diakui secara tidak langsung oleh Pemerintah Indonesia ketika mengesahkan Undang-Undang Nomor 21 Tahun 2001 tentang

\footnotetext{
J. Kristiadi, “Takut dengan Partai Lokal?,” Kompas, 19 Juli 2005.

lbid.

30 Eko Prasojo, "Konstruksi Ulang Hubungan Pemerintah Pusat dan Pemerintah Daerah di Indonesia: Antara Sentripetalisme dan Sentrifugalisme," pidato pada Upacara Pengukuhan sebagai Guru Besar Tetap Fakultas IImu Sosial dan IImu Politik Universitas Indonesia, Depok, 13 September 2006, hlm. 9-10. Masih mengenai
} 
Otonomi Khusus bagi Provinsi Papua (UU Otonomi Khusus Papua 2001) dan UU Pemerintahan Aceh 2006. ${ }^{31}$ Bagian Menimbang butir $f$ dan $g$ dari UU Otonomi Khusus Papua 2001 menyebutkan bahwa:

"f. bahwa penyelenggaraan pemerintahan dan pelaksanaan pembangunan di Provinsi Papua selama ini belum sepenuhnya memenuhi rasa keadilan, belum sepenuhnya memungkinkan tercapainya kesejahteraan rakyat, belum sepenuhnya mendukung terwujudnya penegakan hukum, dan belum sepenuhnya menampakkan penghormatan terhadap hak asasi manusia di Provinsi Papua, khususnya masyarakat Papua; g. bahwa pengelolaan dan pemanfaatan hasil kekayaan alam Provinsi Papua belum digunakan secara optimal untuk meningkatkan taraf hidup masyarakat asli, sehingga telah mengakibatkan terjadinya kesenjangan antara Provinsi Papua dan daerah lain, serta merupakan pengabaian hak-hak dasar pendudukasli Papua;..." (huruf miring oleh penulis)

Kemudian bagian Menimbang butir d dari UU Pemerintahan Aceh 2006 turut menyebutkan:

"bahwa penyelenggaraan pemerintahan dan pelaksanaan pembangunan di Aceh belum dapat sepenuhnya mewujudkan kesejahteraan rakyat, keadilan serta pemajuan, pemenuhan, dan perlindungan hak asasi manusia sehingga Pemerintahan Aceh perlu dikembangkan dan dijalankan berdasarkan prinsip-prinsip kepemerintahan yang baik" (huruf miring oleh penulis).

Lebih lanjut lagi dalam bagian Penjelasan Umum UU Pemerintahan Aceh 2006 disebutkan bahwa:

“...Dalam perjalanan penyelenggaraan keistimewaan Provinsi Daerah Istimewa Aceh dipandang kurang memberikan kehidupan di dalam keadilan atau keadilan di dalam kehidupan. Kondisi demikian belum dapat mengakhiri pergolakan masyarakat di Provinsi Daerah Istimewa Aceh yang dimanifestasikan dalam berbagai bentuk reaksi. Respon pemerintah dan Dewan Perwakilan Rakyat melahirkan salah satu solusi politik bagi penyelesaian persoalan Aceh berupa UndangUndang Nomor 18 Tahun 2001 yang mengatur penyelenggaraan otonomi khusus bagi Provinsi Daerah Istimewa Aceh sebagai Provinsi

\footnotetext{
ketimpangan ekonomi yang dialami oleh rakyat Aceh dan Papua yang mendorong timbulnya gerakan separatis di kedua provinsi itu, dapat dilihat juga pada Syamsul Hadi (et. al.), Disintegrasi Pasca Orde Baru: Negara, Konflik Lokal dan Dinamika Internasional, Jakarta: Yayasan Obor Indonesia, 2007, hlm. 49-51 dan 112-115, serta Jacobus Perviddya Solossa, Otonomi Khusus Papua: Mengangkat Martabat Rakyat Papua di dalam NKRI, Jakarta: Pustaka Sinar Harapan, 2005, hlm. 16.

31 Endra Wijaya, Partai Politik Lokal di Indonesia, Bekasi: F-Media, 2010, hlm. 52.
} 
Nanggroe Aceh Darussalam. Dalam pelaksanaannya, undang-undang tersebut juga belum cukup memadai dalam menampung aspirasi dan kepentingan pembangunan ekonomi dan keadilan politik. Hal demikian mendorong lahirnya Undang-Undang tentang Pemerintahan Aceh dengan prinsip otonomi seluas-luasnya. Pemberian otonomi seluas-luasnya di bidang politik kepada masyarakat Aceh... dimaksudkan untuk sebesar-besarnya kemakmuran masyarakat di Aceh..." (huruf miring oleh penulis)

Persoalan-persoalan ketidakadilan itulah yang kemudian mendorong sebagian rakyat Aceh untuk memperjuangkan nasib mereka melalui wadah berupa organisasi perlawanan seperti GAM. Tentu saja perlawanan yang dilakukan oleh GAM tidak hanya berada di level fisik, politik, dan diplomasi, tetapi juga di level budaya melalui simbol-simbol yang mereka ciptakan untuk mengomunikasikan ideide, cita-cita, dan identitas mereka sebagai suatu kelompok kepentingan. Salah satu bentuk dari simbol yang digunakan oleh GAM adalah berupa bendera bulan sabit dan bintang.

\section{Kaitan Bendera Bulan Sabit dan Bintang dengan Persoalan Separatisme}

Sebelum penandatanganan MoU atau pada masa konflik masih berlangsung antara Pemerintah Indonesia dan GAM, GAM sebenarnya memiliki 3 (tiga) simbol penting, termasuk yang berbentuk bendera, yaitu: simbol bouraq dan singa yang mengapit bulan sabit dan bintang; simbol berupa bendera berwarna hijau dengan tulisan kalimat Tauhid berbahasa Arab (mengacu kepada bendera Negara Arab Saudi); serta simbol bendera bulan sabit dan bintang dengan latar belakang berwarna merah. ${ }^{32}$ Simbol bendera bulan sabit dan bintang dengan latar belakang berwarna merah (bendera bulan sabit dan bintang) inilah yang pada masa konflik lebih populer dikenal sebagai bendera GAM. Bendera itu jugalah yang saat ini telah disahkan sebagai bendera Aceh melalui Qanun Bendera dan Lambang Aceh 2013.

Bendera bulan sabit dan bintang pada masa konflik hingga sekarang telah diidentikkan dengan bendera kelompok separatis di Aceh (GAM), dan hal itu disebabkan antara lain oleh alasan-alasan sebagai berikut: Pertama, bendera bulan sabit dan bintang pada masa konflik menjadi bendera yang dipilih oleh GAM sebagai simbol dari kombatan mereka dalam bergerilya di lapangan. ${ }^{33}$ Dalam hal ini, bendera bulan sabit dan bintang itu telah difungsikan sebagai pembeda antara yang mana kawan dan yang mana lawan dalam sebuah medan pertempuran (konflik). ${ }^{34}$ Kedua, bendera bulan sabit dan bintang pada masa konflik sering dikibarkan pada tempat-tempat tertentu, yang mana hal ini kemudian direspons oleh Pemerintah

32 Indra Jaya Piliang, Bouraq-Singa Kontra Garuda: Pengaruh Sistem Lambang dalam Separatisme GAM terhadap RI, Yogyakarta: Ombak, 2010, hlm. 83 dan 86.

33 Ibid., hlm. 88-89.

34 Thomas Hylland Eriksen dan Richard Jenkins (eds.), Loc.cit. 
Indonesia karena dianggap sebagai bentuk gangguan keamanan terhadap kedaulatan NKRI. ${ }^{35}$ Ketiga, sebagai akumulasi kedua alasan di atas, maka secara yuridis melalui PP Lambang Daerah 2007 telah ditetapkan bahwa bendera bulan sabit seperti yang digunakan oleh gerakan separatis di Aceh, yaitu GAM, tidak boleh digunakan sebagai lambang daerah (logo dan bendera daerah).

Namun demikian, fakta yang terjadi di Aceh sekarang terkait dengan bendera Aceh ternyata menjadi permasalahan yang belum terselesaikan. Pada tanggal 25 Maret 2013, telah diundangkan Qanun Bendera dan Lambang Aceh 2013. Salah satu yang menjadi permasalahan utama dari diberlakukannya Qanun Bendera dan Lambang Aceh 2013 itu adalah ditetapkannya bendera bulan sabit dan bintang menjadibendera Aceh.

Beberapa pihak yang berwenang bereaksi dengan menyatakan ketidaksetujuannya terhadap pengesahan bendera bulan sabit dan bintang sebagai bendera Aceh. Pihak pemerintah pusat, melalui Kementerian Dalam Negeri, telah mengirimkan Surat Klarifikasi atas Qanun Bendera dan Lambang Aceh 2013 dari Menteri Dalam Negeri, tetapi tindak lanjut dari surat tersebut masih belum jelas sampai sekarang.

Dengan terdapatnya beberapa ketentuan di dalam Qanun Bendera dan Lambang Aceh 2013 yang bertentangan dengan kepentingan umum dan peraturan perundang-undangan yang lebih tinggi serta aturan dalam pembuatan legal drafting, maka pada bagian akhir surat klarifikasi tersebut Menteri Dalam Negeri meminta agar Pemerintah Aceh segera menyesuaikan substansi Qanun Bendera dan Lambang Aceh 2013 dengan ketentuan peraturan perundang-undangan terkait yang hierarkinya lebih tinggi, paling lama 15 (lima belas) hari sejak diterimanya surat klarifikasi.

Salah satu kendala dalam menyelesaikan problem bendera Aceh ini juga disebabkan karena masih kuatnya dukungan Partai Aceh bagi bendera Aceh yang telah dibentuk dan disahkan melalui Qanun Bendera dan Lambang Aceh 2013. Sebagaimana diketahui bahwa memang secara historis dan emosional, Partai Aceh jelas memiliki hubungan yang erat dengan eksistensi bendera Aceh yang bergambar bulan sabit dan bintang.

Mengenai adanya dukungan Partai Aceh bagi bendera Aceh yang bergambar bulan sabit dan bintang tersebut diungkapkan oleh narasumber yang tim peneliti wawancarai. Saat tim peneliti wawancarai, Pejabat Kepala Seksi Pemerintahan Aceh, Direktorat Jenderal Otonomi Daerah, Kementerian Dalam Negeri, menjelaskan bahwa:

"Dikaitkan dengan klarifikasi resmi terhadap Qanun Nomor 2 Tahun 2013 dan Nomor 3 Tahun 2013, Kementerian Dalam Negeri sudah

35 Indra Jaya Piliang, Loc. cit. 
berupaya melakukan perundingan untuk menyelesaikan sengketa, akan tetapi tampaknya Gubernur Aceh tidak berdiri sendiri, tetapi dia juga disokong oleh Partai Aceh [yang] membantu mereka. Jadi indikasi apakah ada kemauan Gubernur Aceh untuk merespons klarifikasi dari Kementerian Dalam Negeri sedikit banyak akan terpengaruh oleh pendapatnya Partai Aceh. Kecuali Gubernur menentang pemikiran dari Partai Aceh. Dewan Perwakilan Rakyat Aceh [juga] mayoritas berasal dari Partai Aceh." ${ }^{36}$ (tanda kurung siku oleh penulis)

Lebih lanjut, sebagaimana hasil wawancara tim peneliti dengan Pejabat Kepala Seksi Pemerintahan Aceh, Direktorat Jenderal Otonomi Daerah, serta Kementerian Dalam Negeri; pihak Kementerian Dalam Negeri juga 'khawatir' bahwa upaya pengesahan bendera bulan sabit dan bintang sebagai bendera Aceh akan menjadi salah satu langkah yang ditempuh oleh pihak-pihak tertentu di Aceh untuk secara perlahan-lahan melepaskan diri dari NKRI.

\section{E. Penutup}

Berdasarkan pembahasan-pembahasan di atas, maka keberadaan bendera bulan sabit dan bintang, sebagaimana disahkan melalui Qanun Bendera dan Lambang Aceh 2013, dapat dilihat sebagai simbol yang identik dengan perlawanan terhadap dominasi pemerintah pusat terhadap daerah, dalam hal ini Aceh. Bahkan dari sisi historis, pada saat konflik di Aceh masih berlangsung, bendera bulan sabit dan bintang ini telah menjadi simbol dari cita-cita untuk memerdekakan diri dari NKRI.

Namun selain hal tersebut, bendera bulan sabit dan bintang juga tidak bisa dilepaskan dari persoalan ketidakadilan yang dahulu menimpa rakyat Aceh yang kemudian diperjuangkan oleh GAM. Oleh karena itu, keberadaan bendera bulan sabit dan bintang sebagai bendera Aceh dapat dilihat juga sebagai simbol 'koreksi' atas ketidakadilan yang pernah dialami oleh rakyat Aceh. Atau dengan kata lain, bendera Aceh ini dapat pula dipahami sebagai salah satu sarana untuk memberikan rasa keadilan bagi rakyat Aceh yang pernah diperlakukan tidak adil oleh penguasa.

Penjelasan di atas sebenarnya menyiratkan adanya 'ketegangan' di antara isu separatisme dan akses keadilan bagi rakyat Aceh. Di satu sisi, jika bendera bulan sabit dan bintang tetap dibiarkan menjadi bendera Aceh, maka seolah-olah membiarkan simbol separatisme hadir di dalam NKRI. Hal ini sekaligus menciptakan keadaan saling berbenturan antara kedua jenis peraturan perundang-undangan, yaitu PP Lambang Daerah 2007 yang lebih tinggi hierarkinya dan Qanun Bendera dan Lambang Aceh 2013 yang lebih rendah kedudukannya.

Di sisi lain, jika Qanun Bendera dan Lambang Aceh 2013 dibatalkan keberlakuannya, maka akses keadilan bagi rakyat Aceh, setidaknya keadilan dari

36 Wawancara tim peneliti, Loc.cit. 
ketertindasan di masa lalu serta keadilan budaya (kenangan terhadap masa lalu), akan menjadi terhambat pula pemenuhannya. Bagi Pemerintah Pusat, bendera Aceh ini bertentangan dengan kepentingan umum dan peraturan perundangundangan yang lebih tinggi, misalnya saja apabila dilihat dari sudut ketentuan Pasal 6 ayat (4) PP Lambang Daerah 2007 beserta penjelasannya. Sedangkan bagi Pemerintah Aceh, mereka tetap menganggap bahwa bendera Aceh itu sah serta memiliki landasan keberlakuan yang kuat. Maka dari itu, untuk permasalahan bendera Aceh ini, baik bagi pihak Pemerintah Pusat maupun pihak Pemerintah Aceh memang dituntut untuk sama-sama bersedia 'mundur selangkah' demi kemajuan serta kebaikan bersama.

Tafsir (interpretasi) yang baru sebaiknya dilakukan dalam memaknai bendera bulan sabit dan bintang yang dipilih menjadi bendera Aceh, sehingga bendera tersebut dapat lebih memiliki makna yang cocok bagi keberlangsungan hubungan antara Aceh dengan Pemerintah Pusat dalam bingkai NKRI pada masa sekarang dan mendatang. Selain itu, harus ada kesediaan pula dari Pemerintah Pusat untuk tidak lagi memaknai bendera bulan sabit dan bintang sebagai bendera kelompok separatis yang dahulu pernah berkonflik dengan Pemerintah Pusat. Hal yang harus dibangun adalah pemahaman bahwa bendera bulan sabit dan bintang itu adalah salah satu simbol dari keragaman budaya yang berasal dari Aceh yang bisa semakin memperkaya dan menguatkan bangunan NKRI yang didirikan di atas pluralisme.

Tafsir (interpretasi) yang baru tersebut selanjutnya perlu juga diikuti dengan upaya untuk merevisi peraturan perundang-undangan yang mengatur atau berhubungan dengan bendera daerah. Khususnya terkait dengan permasalahan bendera Aceh, Pemerintah Pusat mungkin perlu melakukan revisi setidaknya untuk frasa "pada pokoknya atau," sehingga ketentuan Pasal 6 ayat (4) tersebut menjadi berbunyi:

"Desain logo dan bendera daerah tidak boleh mempunyai persamaan keseluruhannya dengan desain logo dan bendera organisasi terlarang atau organisasi/perkumpulan/lembaga/gerakan separatis dalam Negara Kesatuan Republik Indonesia." (huruf miring oleh penulis).

Dengan kalimat seperti itu, diharapkan tetap dapat memberi ruang bagi kehendak rakyat Aceh untuk tetap dapat 'bernostalgia dengan masa silam'.

Begitu pun dengan pihak Pemerintah Aceh yang setidaknya bisa melakukan revisi terhadap Qanun Bendera dan Lambang Aceh 2013 agar gambar dan komposisi bentuk serta warna yang digunakan untuk bendera Aceh agar tidak lagi sama persis dengan bendera GAM. Selain itu, Pemerintah Aceh dapat juga merevisi makna-makna yang terkandung di dalam bendera Aceh, sebagaimana tercantum dalam Lampiran I Qanun Bendera dan Lambang Aceh 2013. Mungkin saja di dalam makna-makna dari setiap gambar dan komposisi bentuk serta warna bendera Aceh tersebut bisa disisipkan kalimat yang menjelaskan jaminan dukungan Pemerintah 
Aceh terhadap eksistensi NKRI. ${ }^{37}$

\section{Daftar Pustaka}

\section{Buku}

Benny H. Hoed, Semiotik dan Dinamika Sosial Budaya, Fakultas IImu Pengetahuan Budaya Universitas Indonesia, Depok, 2008.

Endra Wijaya, Partai Politik Lokal di Indonesia, F-Media, Bekasi, 2010.

Eriksen, Thomas Hylland dan Richard Jenkins (eds.), Flag, Nation and Symbolism in Europe and America, Routledge, London dan New York, 2007.

Hestu Cipta Handoyo, Prinsip-Prinsip Legal Drafting dan Desain Naskah Akademik, Cahaya Atma Pustaka, Yogyakarta, 2014.

Indra Jaya Piliang, Bouraq-Singa Kontra Garuda: Pengaruh Sistem Lambang dalam Separatisme GAM terhadap RI, Ombak, Yogyakarta, 2010.

Jacobus Perviddya Solossa, Otonomi Khusus Papua: Mengangkat Martabat Rakyat Papua di dalam NKRI, Pustaka Sinar Harapan, Jakarta, 2005.

Mochtar Kusumaatmadja, Bunga Rampai Hukum Laut, Bina Cipta, Bandung, 1978.

Alumni, Bandung, 2003. dan Etty R. Agoes, Pengantar Hukum Internasional,

Pedersen, Christian Fogd, The International Flag Book in Colour, Blandford Press, London, 1971.

Shidarta (eds.), Mochtar Kusuma-Atmadja dan Teori Hukum Pembangunan:

Eksistensi dan Implikasi, Epistema Institute dan HuMa, Jakarta, 2012.

Sri Soemantri, Tentang Lembaga-Lembaga Negara Menurut UUD 1945, PT. Citra Aditya Bakti, Bandung, 1993.

Syamsul Hadi (et al.), Disintegrasi Pasca Orde Baru: Negara, Konflik Lokal dan Dinamika Internasional, Yayasan Obor Indonesia, Jakarta, 2007.

Taufik Al Mubarak, Aceh Pungo, Bandar Publishing, Banda Aceh, 2009.

\section{Dokumen Lain}

Eko Prasojo, "Konstruksi Ulang Hubungan Pemerintah Pusat dan Pemerintah Daerah di Indonesia: Antara Sentripetalisme dan Sentrifugalisme," pidato pada Upacara Pengukuhan sebagai Guru Besar Tetap Fakultas IImu Sosial dan IImu Politik Universitas Indonesia, Depok, 13 September 2006.

Hamid Awaludin, "Bendera Aceh," http://regional.kompas.com/read/2013/04/09/ 02242125/Bendera.Aceh, diakses 15 April 2013.

J. Kristiadi, "Takut dengan Partai Lokal?," Kompas, 19 Juli 2005.

Lintas Gayo, "Inilah 81 Calon Terpilih Anggota DPRA 2014-2019 dari 23 Kabupaten Kota," http://www.lintasgayo.com/48401/inilah-calon-terpilih-anggota-

$37 \quad$ lbid. 
172 PJIH Volume 3 Nomor 1 Tahun 2016 [ISSN 2460-1543] [e-ISSN 2442-9325]

dpra-2014-dari-23-kabupaten-dan-kota.html, diakses 19 Mei 2015.

M. Rizwan Haji Ali dan Nezar Patria, "Dari Senjata ke Kotak Suara: Peralihan Gerakan Aceh Merdeka ke Politik Elektoral," Prisma 1, Vol. 28, Juni 2009.

Sar, "Bendera Aceh, Bintang Bulan Harus Diubah", http://aceh.tribunnews.com/2013/09/14/bintang-bulan-harus-diubah/, diakses 5 November 2014. 